\title{
A República segundo Hobbes: o Corpo ou a Razão?*
}

\author{
Jean Mathiot**
}

\begin{abstract}
Resumo: Este artigo tenta mostrar como a concepção hobbesiana de corpo, longe de ser uma mera metáfora ou o efeito de uma redução fisicalista, constitui antes uma significação primeira para toda ciência possível. A partir dela, é possível pensar o que é o conpo político sem cair em ilusões substancialistas ou totalizantes.
\end{abstract}

Palavras-chave: corpo político - organismo - hobbesianismo

A insistência com a qual Hobbes promove a noção de corpo político para designar a Cormonwealth, de cuja instituição faz a teoria, é ao mesmo tempo um enigma e um obstáculo. Talvez, de início, um obstáculo para a compreensão de sua "ciência política". Pois a metáfora do corpo, já desgastada em sua época pela tradição do modelo orgânico do político, a ponto de enfrentar uma verdadeira crise ${ }^{(1)}$, peca por numerosos equívocos, tanto herdados de seus usos anteriores quanto constitutivos de sua própria natureza. O enigma, por sua vez, deve-se então à aparente cegueira de Hobbes

* Gérard Lebrun me havia concedido a honra e amizade de dedicar um de seus artigos sobre Hobbes, intitulado Hobbes e a Instituição da Verdade. Considero novamente uma honra poder prolongar este diálogo amigável.

** Professor da Universidade de Provence Aix-Marseille. Tradução de Maria das Graças de Souza Nascimento. 
em relação a estes equívocos. Mesmo fazendo-se abstração de seu passado, a metáfora apresenta uma dupla incerteza. Em primeiro lugar, não seria uma confissão de impotência da filosofia política contar com os privilégios de um conceito criado e explicado fora dela, como sendo o único capaz de dar testemunho de algumas propriedades do Estado? O fato é tanto mais surpreendente num autor explicitamente inimigo do pensamento analógico e do uso não controlado das metáforas. O corpo político seria então o sinal de um limite da razão do político, a prova de uma dependência subterrânea, embora fundamental, da filosofia política em relação à filosofia natural ou à metafísica do real?

O outro equívoco subsistiria então mesmo que se negligenciasse ou ao contrário se elucidasse o primeiro. O que é que se diz de maneira insubstituível na metáfora política do corpo da República? Aqui, uma vez pago o preço pelo uso do termo, interrogamo-nos sobre seu benefício. Sem dúvida, a unidade do conpo, seu caráter irredutível a outra coisa a não ser a outros corpos, como dizia Aristóteles ${ }^{(2)}$, fornecem, para além do que é dizível segundo a razão política sozinha, uma outra base para propriedades de consistência, que, precisamente, não poderiam ser ditas de outro modo. Ao autorizar uma forma de unidade que por si mesma não precisa ser interrogada, a noção de corpo poderia então servir de verdadeiro novo ponto de partida para a derivação das consequiências do Estado político. Este não precisaria referir-se mais a não ser a si mesmo para esclarecer aquelas. Uma outra razão se apresentaria então, ligada somente a esta auto-suficiência da República considerada como corpo, considerável apenas segundo o ponto de vista de sua interioridade. Este benefício esboçado é realmente aquele que Hobbes espera? Aqui mais uma vez somos tomados de perplexidade, se é verdade que Hobbes se dedica precisamente a sondar os segredos da origem da Cormonwealth, e que os conceitos de convenção, de poder soberano, de "pessoa", de representante etc., parecem poder dispensar o uso da noção de corpo para dar conta da unidade real da Commonwealth. É concebível que Hobbes tenha julgado estes conceitos insuficientes ao ponto de substituílos pelo termo ao mesmo tempo menos específico e mais obscuro de "corpo"? Aliás, a dificuldade não temina com esta constatação: pois, num autor que, como ele, define explicitamente o corpo como algo a respeito do qual não podemos conceber a geração nem a destruição (3) , é mais do que paradoxal fazer dele um uso destinado a explicar a unidade política, que ele havia se esforçado em construir elucidando precisamente sua origem...

A interpretação de toda a filosofia política de Hobbes pode aqui sofrer um abalo. Se for uma confissão de retorno ao pensamento analógico, o corpo político assinala a insuficiência do conjunto da doutrina; se for uma antecipação, mesmo infundada, de uma racionalidade do Estado que conviria considerar como derivada do fato de sua existência, então devemos orientar nossa interpretação, livres para passar por cima das imperfeições da demonstração hobbesiana, em direção à modernidade da razão de Estado, e mesmo do Estado racional.

Será que estes desafios chegam a se esclarecer durante a evolução do pensamento de Hobbes? Nota-se, é certo, que o tema explícito do "corpo político", que dá nome à segunda parte da primeira obra importante, os Elements of law (o De conpore politico, publicado em 1650, embora o título talvez seja apócrifo) perde um pouco o terreno com a emergência do texto que, segundo o próprio Hobbes, marca o ponto de partida de seu verdadeiro método, ou seja, o De cive. No prefácio da obra, constatamos que o termo desapareceu completamente. No capítulo V, consagrado à instituição da cidade, ele reaparece; mas pode-se observar ainda que na edição inglesa de 1651, mais tardia, ele é substituído por "pessoa" em todas as ocorrências deste mesmo capítulo V. Assim somos levados a esboçar a hipótese de um abandono progressivo do termo por parte de Hobbes, pelo menos no que diz respeito ao seu valor para a análise da instituição. Contudo, permanece o fato de que esta hipótese é mal validada pelo texto do Leviatã: se Hobbes, no capítulo XVII, dedicado à geração da Commonwealth, se abstém de qualquer referência a um corpo político, é para dar de novo, na sequiência, livre curso a esta terminologia, a ponto de construir a partir do modelo orgânico toda a doutrina política do homem artificial, de suas partes, de suas funções, de suas doenças e remédios... O abandono é pois apenas parcial, e diria respeito à menção do corpo enquanto relacionada à produção da Commonwealth. Não se pediria mais ao corpo que representasse a unidade engendrada da República. Por outro lado, o fato de este abandono ser parcial não deixa de surpreender: a partir de que partilha sutil o termo seria 
aceitável num lugar e não num outro, quando, em todos os casos, trata-se de uma mesma realidade, a da República?

\section{O que é um corpo?}

Não é nada invejável ter de escolher entre a confissão de uma insuficiência conceitual - paga com o alto preço da metaforização - e a ingenuidade de um fisicalismo fora de propósito. Como Hobbes acomoda sua ambição de criador da ciência política com esta dupla suspeita?

No início, ele designa como corpo tudo o que é concebível e tudo o que pode ser objeto de ciência (4) - "Conpos naturais" e "corpos políticos" resumem assim todo o domínio do saber ${ }^{(5)}$. Nenhuma analogia é aqui admissível com o ponto decisivo desta partilha, que supõe antes um valor universal para a noção de "corpo".

Esta noção não poderia fornecer a universalidade do conceito de objeto de ciência sem abandonar, antes de mais nada, a acepção exclusiva da física. O itinerário de Hobbes acompanha suficientemente bem as lições da nova física galileana para medir todas as consequiências do movimento estado distinto dos estados substanciais. Uma destas conseqüências é justamente a crise em que se viu mergulhada a noção de corpo. Hobbes compreende o seu alcance, acrescentando ainda, sem privilegiar um em relação a outro, dois problemas, o da relatividade física do movimento e o da relatividade ótica. Desde o Curto Tratado sobre os primeiros princípios, datado sem dúvida de 1630, ele se lança à procura de uma nova noção de agente que seja capaz de dar tanto à ótica quanto à mecânica um novo significado para a substância.

Se em Descartes, o problema desta substância em movimento torna-se rapidamente um tema reavaliado à luz de uma ordem metafísica de razões, Hobbes segue passo a passo todos os acasos e complicações de uma ordem de matérias mantida até mesmo no terreno da significação. Não é de se espantar, desde então, se, por uma espécie de quiasmo, o corpo recebe em Descartes seu sentido mecanista na mesma medida em que o problema físico foi subordinado à metafísica, enquanto que Hobbes, pelo fato de deixar as questões mais árcuas concernentes à substância fora de qualquer auxílio metafísico, acaba dando um sentido categorial ao termo conpo, sobrecarregado de toda a herança e dos interesses da substância. Portanto, não é ele que se prende a um mecanismo dos corpos em movimento: o sentido menos mecanista de corpo é aquele proposto por Hobbes, prefigurando bem frequientemente no De corpore as primeiras críticas que Leibniz dirigirá contra o mecanismo.

Para compreender esta significação categorial hobbesiana de "corpo" talvez seja necessário invocar o fracasso relativo de seus empreendimentos na ótica: neste caso, a doutrina da sensação se revelou ao mesmo tempo como uma passagem obrigatória para uma doutrina do corpo, se esta ordem de matérias - primeira forma essencial de inspiração empirista de Hobbes deve ser seguida com exclusividade, e contudo como uma passagem sem saída; pois a ótica, que coloca o problema mais difícil, já presente em Bacon, da ação à distância, não encontra solução a não ser fazendo surgìr um outro corpo além do corpo sensível, o corpo que sente, que longe de poder ser erigido em categoria a priori da realidade, só poderia ser emprestado da ordem dos fatos. Do objeto visível ao corpo que sente, o deslocamento da investigação é inevitável, mas sobretudo cheio de dificuldades. Quando ele assinala, parece que com um certo pesar, que nem todos os corpos são dotados de sensação ${ }^{(6)}$ trata-se da entrada em cena de um conceito de corpo que está presente. O que é um corpo em geral se a única atualidade de referência é fornecida pela sensação que dele deriva?

A vontade filosófica de não se limitar apenas aos recursos da atualidade de nossas sensações (incluindo nossas imaginações, nossas concepções. . . ) é manifesta na definição clássica e célebre enunciada no De corpore: . . . "aquilo que, não dependendo de nossa concepção (cogitatio) coincide ou é coextensivo com uma parte do espaço" (II, capítulo VII, parágrafo I) . A atualidade de nossa concepção é ao mesmo tempo requerida e insuficiente. Requerida com o espaço, que é imaginário; insuficiente pelo fato da intervenção da "coincidência" de uma coisa com uma parte do espaço.

A solução do problema assim colocado de apreender conceitualmente no corpo uma realidade independente de nosso espírito não passa evidentemente apenas pela condição espacial. A "coincidência" evocada implica uma 
espécie de verificação do real que é problemática: ao mesmo tempo está em nossa concepção, e todavia não depende dela. A verdadeira resposta situase na noção de corpo como significação. É preciso aqui lembrar o esquema engenhoso que faz do nome de corpo um nome "concreto" privilegiado, a primeira categoria do real. Diferentemente da res, que é denotada apenas pela sua simples denominação, e que pode ser real ou fictícia (7) , o "corpo" não deriva desta função denotativa, mas antes da função conotativa: retomando aqui, sem dizê-lo, o essencial da doutrina ockamiana da conotação, Hobbes assimila o nome de "corpo" a um adjetivo como "branco" ou "móvel" (motum) ${ }^{(8)}$ : como em Ockham, onde "branco" denota uma coisa, mas conota brancura, "corpo" denota uma coisa, mas conota a "corporeidade" ou a "extensão". Este nome abstrato, por sua vez, denota a causa do nome concreto( ${ }^{(9)}$. É de se notar já esta motivação da significação pelas causas como o ponto forte da exigência nominalista de Hobbes: não promover o arbitrário como indiferença das escolhas, mas ao contrário como ocasião de discriminá-las em função das causas da própria nominação...

Contudo, o esquema não é ainda perfeito apenas com a menção da motivação do nome de corpo. Pois doravante tudo se move na concepção desta corporeidade ou desta extensão: não há neste caso o risco de regressão a uma análise desta corporeidade, pressuposta, mas que ainda não foi feita? A tentação fisicista deve ser outra vez abandonada: não se trata de construir nenhuma doutrina especial da corporeidade, pois a corporeidade só é causa enquanto designa, finalmente, a relação ao próprio corpo. O círculo assim se fecha numa perfeita reciprocidade: "corpo" remete por conotação a corporeidade, a qual é por sua vez a causa específica do nome de "corpo" como nome concreto.

Teria esta reciprocidade os vícios da circularidade que se atribui facilmente a um tal jogo nominal? Este seria o caso se considerássemos precisamente como dado o nome de "corpo". Então, a reciprocidade em questão só o desenvolveria como sua própria causa. Mas isto não ocorre, pois tratase justamente da emergência do nome de corpo. Para Hobbes, os nomes não podem ser tomados como dados de uma análise. Pois assim ele se veria prisioneiro de seu jogo. Dar um nome é um ato que deve ser tomado a partir de suas condiçães. No caso do corpo, esta condição é especialmente preen- chida por esta reciprocidade, pois não conviria que o nome de corpo dependesse de uma definição da corporeidade que exigisse um conhecimento anterior, fazendo-o assim depender novamente de nossas concepções. O mesmo traço já se encontrava em Ockham, que distinguia entre os conotativos que remetiam à existência ou ao conhecimento de uma outra coisa (por exemplo, a causalidade), e os conotativos que não exigiam uma tal regressão (como a quantidade) ${ }^{(10)}$ - O fato de que a remissão conotativa do conpo à corporeidade não reclame uma referência a nenhuma outra coisa a não ser o próprio conpo é que faz dele um termo absoluto, tendo valor de substância.

Esta conporeidade, todavia, não é vazia de conteúdo: ela será, se quisermos, a essência do corpo: Hobbes a define pela extensão e, de modo mais geral, por todos os acidentes sem os quais o corpo não poderia ser, já que os acidentes são indissociáveis dele. A corporeidade é pensada na relação entre o corpo e o acidente. Hobbes, assim como Kant, pensa a substância como relação. É que, antes de tudo, ele não quer recair numa dependência da noção de corpo em relação a um discurso sobre a essência do corpo: o vício da metafísica é sempre fazer da essência um ser, ou, inversamente, fazer o ser depender de uma essência. É assim que se é tentado a passar da res extensa, que é o corpo, à extensão real, que para Hobbes é apenas um ser fictício nascido da imaginação metafísica. Pensar o corpo como verdadeiramente independente de nossas concepções, eis o que Descartes não soube fazer, nos diz paradoxalmente o nominalista Hobbes ${ }^{(11)}$.

Toda esta discussão sobre a res extensa e a extensão é evidentemente importante para o valor de categoria do real do termo corpo, capaz de designar o que em nenhum caso poderia ser reduzido a uma parte do espaço material: Deus, a República... e que todavia recebe em Hobbes a denominação de corpo. Que esta denominação não seja nem uma metáfora nem o efeito de uma redução fisicalista ou materialista, isso depende do estabelecimento dos direitos do empreendimento hobbesiano, que consiste em fazer do corpo uma significação primeira para toda ciência possível.

Três observações gerais sobre esta noção de corpo ajudarão talvez ajudarão a que se possa admiti-la. Em primeiro lugar, Hobbes atribui ao nome de corpo a função insubstituível de dar lugar, em nossa concepção, àquilo que não depende de nossa concepção, uma realidade exterior a nosso espírito. 
Só o nome pode fazer esta façanha. Pois a ordem dos nomes corresponde à ordem de nossas concepções, mas esta mesma ordem não corresponde absolutamente à ordem dos corpos, ou seja, das realidades exteriores ao nosso espírito ${ }^{(12)}$. Donde a importância do valor conotativo do nome, pelo qual ele pode ultrapassar a simples dependência em relação à nossa concepção atual, envolvendo ou suscitando uma outra. Graças ao nome, a existência real entra em nossa conceptibilidade, sob a forma de uma posição absoluta de uma realidade sempre singular, mas que nos faz reencontrar os privilégios da substância dos filósofos.

É preciso insistir, em seguida, sobre o valor de verificação que está ligado à concepção hobbesiana de corpo. Por si só, a atualidade de nossa concepção (a imaginação) não basta para inscrever o corpo como verdade. Apenas o ato de nomear, tomado como arbitrário humano, evidentemente também não traz uma nova atualidade, capaz de ultrapassar esta atualidade de um sentir ou de um agir, que não pode receber em Hobbes uma plena acepção subjetiva, como será o caso nos empiristas do século XVIII. A própria representação é impotente para fixar um objeto visível como corpo. Nos termos da ótica hobbesiana, a unidade do objeto representado é submetida à prova da multiplicidade dos pontos de vista dos que sentem, que são, cada um, um lugar diferente de representação.

Na coincidência evocada por Hobbes entre o espaço imaginário e o espaço real, entra pois uma outra forma de atualidade que vem resolver estes problemas, ao confimar e completar a atualidade da subjetividade que sente, fornecendo a condição de acesso a um tratamento do real segundo a razão. Esta outra forma de atualidade não pode vir nem da ação do sujeito que sente enquanto tal (já que é precisamente daquilo que não depende dele que ela precisa emergír) , nem da ação do objeto que é o correlato da sensação ou da imaginação: o dojeto sensível não poderia fornecer um modelo do corpo como realidade, já que justamente a nova ótica estabeleceu que a pressuposição do corpo que sente é precisamente necessária à sua constituição. Decididamente, a ordem das matérias não oferece as mesmas facilidades que a ordem das razões, e não se deve esperar nenhuma garantia de verdade de uma razão superior. Qual é pois a atualidade capaz de trazer a imagem da coisa para a realidade do corpo?
A resposta só pode ser dada por Hobbes por meio de uma nova ocorrência de ação. Fazer coincidir o espaço imaginário com uma porção do espaço "real" é superpor à atualidade da imaginação uma outra atualidade, a de um agente que se constitui como sujeito de uma ação que se acrescenta à atualidade da sensação do sujeito que percebe. Esta nova ação, que vem conservar e confimar o fantasma da realidade do sujeito que sente, não toma portanto necessariamente a forma de um correlato objetivo que se opõe a ele. o corpo não é somente o "outro" do sujeito: talvez seja o homem, na mesma medida, que se constitui em sua ação - suas paixões e seus movimentos. O homem artificial, vê-se, estará bem no prolongamento do homem que sente.

A atualidade que vem assim realizar, confimar e de certo modo, fazer o fantasma da realidade exterior aceder à verdade, está longe consequientemente de nos fazer voltar a um mecanismo estreito no qual os corpos se submetem de início à delimitação da extensão substancial. Não somente este mecanismo, estranho a Hobbes, interditaria o acesso da noção de corpo - a não ser como metáfora ousada e custosa - ao domínio completo da ação humana, mas ainda arruinaria as chances de uma verdadeira ciência. Esta, para Hobbes, situa-se no ponto em que nossas significações estejam em condiçães de dominar o que na realidade não depende de nossas concepções.

Sem dúvida, esta atualidade que dá ao "corpo" toda a sua significação não dá lugar a um discurso sobre o corpo em geral, ou a uma ontologia qualquer. O valor universal da noção de corpo não lhe dá uma significação capaz da menor abstração que seja. A atualidade do corpo só pode ser singular e contingente: ela dá lugar a uma verdade universal mas sem que esta verdade tome por sua vez a forma de um novo objeto. Nem verdade como garantia, nem verdade como fonte de nova garantia, o corpo corresponde a uma verdade limitada à atualidade que o faz nascer. Esta atualidade da verdade nos encaminha para o tema do artifício, esta segunda forma de ação que, para além da sensação, reúne as condições desta verdade de um produto que se tornou independente de nossas concepções. A aliança do tema do corpo, realidade independente que não pode ser gerada nem destruída, com o tema do artifício, que é geração, deixa de ser uma monstruosidade ou uma contradição interna. O que os concilia é em primeiro lugar a natureza desta 
atualidade que constitui o corpo, da qual tínhamos constatado que se devia a uma nova ocorrência da ação, vindo substituir a ação da sensação. Sem dúvida, o corpo é rebelde a qualquer geração ou a qualquer destruição, já que ele é irredutível a um objeto apreendido pela sensação. Mas, num outro sentido, a atualidade que lhe dá sua verdade de corpo não deixa de ser uma ação: uma ação produtora, portanto, um artifício.

A última observação diz respeito ao conteúdo desta verificação do real à qual corresponde o nome de corpo, e graças à qual o corpo toma o lugar de um objeto de ciência por excelência. Esta "verificação", de uma natureza particular, passa por um outro aspecto que convém assinalar na atribuição do nome concreto de corpo: sua motivação. Pelo jogo da conotação da conporeidade, e pelo jogo, em sentido inverso, da causalidade que esta corporeidade encarna em relação ao nome concreto, um conpo só é enunciado como tal a partir da base desta motivação que conduz a esta enunciação. O nominalismo, como se disse, longe de reduzir as condições da nominação à indiferença, ultrapassa estas condições. Mas se o nome de corpo é assim motivado pelo conteúdo da corporeidade que fornece a causa do nome concreto, esta motivação não tem nada que se pareça com um fundamento, e simplesmente remete ainda a um movimento. Prova disto é a recusa da extensão substancial, que seria um fundamento dos corpos. A noção de motivação, ao remeter ao ato de uma enunciação que comporta sua razão, não implica que esta razão tome a forma de um fundamento que seria a interrupşão do movimento. Isto seria, ao contrário, confundir a essência da corporeidade - os acidentes indissociáveis do conpo - e o próprio ser do corpo. O estatuto nominal do corpo permite justamente evitar esta confusão: a corporeidade não é um ser.

Ao recusar assim uma ontologia da conporeidade, Hobbes nos esclarece a respeito de dois pontos sensíveis da noção de conpo político, a saber, seu aspecto não espacial e seu aspecto artificial, ambos aparentemente em contradição com o estatuto original de conpo. Com efeito, só uma ontologia da corporeidade, como fundamento da existência do corpo, faria da extensão do corpo a razão única de sua existência; de fato, a substancialidade seria então, aos olhos de Hobbes, transferida do corpo para a corporeidade, ce- dendo assim às ilusões metafísicas que coisificam as essências. Mas é neste caso que o corpo não poderia dar, como di rá Leibniz, "a razão de sua razão".

A diferença entre as cuas versões da conporeidade se mostra em particular no nível de suas consequiências: para a versão metafísica da conporeidade da extensão, esta funcionaria como fundamento do corpo e, em particular, serviria também de fundamento dos acidentes do corpo. Nada que não fosse conporal poderia acontecer a este corpo assim fundado. Reencontraríamos um mecanismo do tipo cartesiano. Inversamente, na versão hobbesiana, a extensão, não substancial, só vale como essência da conporeidade enquanto ela é indissociável do corpo, nada mais. Ela não poderia valer como suporte ou modo de ser para todos os outros acidentes do corpo. Além disso, como a corporeidade definitivamente só se deve à relação indissociável entre os acidentes e o corpo, pode-se conceber uma outra indissociabilidade diferente daquela fomecida pela extensão. E esta outra indissociabilidade não poderia ser pensada apenas a partir da extensão. Hobbes, portanto, nos liberta de um mecanismo estreito. A respeito da própria extensão, incontestavelmente privilegiada por Hobbes, devemos dizer que ela não comanda independentemente do movimento e da ação: pois é na sua ocasião que ela é indissociável do conpo.

É ainda a mesma recusa de uma ontologia da corporeidade que libera sua interpretação artificialista possível. Pois Hobbes substitui um fundamento intrínseco da corporeidade, que seria obra da Criação, ou seja, da Natureza, de maneira exclusiva, por um livre acesso para toda indissociabilidade dos acidentes ligada à ação, e que possa derivar dela. Uma relação deste tipo não é mais marcada necessariamente por uma unidade intrínseca, nem exclusivamente natural. Hobbes dá a entender isto por diversas vezes: é justamente enquanto natural que o corpo é difícil de ser explicado, pois não poderíamos sondar as razões da sua ligação indissociável com os acidentes. Ao contrário, é como correlato do artifício que a ligação indissociável pode ser reconduzida à transparência. Ousemos pois ir até o fim do argumento: o corpo se encontra bem mais estabelecido em sua identidade como obra do artifício do que como obra da Natureza ou da Criação... A introdução do Leviatã e sua preferência provocante pelo homem artificial, criado pelo homem, em relação ao homem saído da Natureza (resumamos o 
argumento: na Natureza, o homem é o ponto de chegada, a "obra mais excelente"; no artifício, este ponto de chegada é o ponto de partida para uma nova obra: "a arte vai mais longe ainda"...) se esclarece com o exame das condições precisas da corporeidade. E podemos assim concluir que se o corpo é rebelde à geração (impossível passar de um não-corpo a um corpo...) , o mesmo não acontece com a corporeidade que dá à afirmação do corpo o motivo de sua atualidade. Uma corporeidade gerada é mais racional do que uma corporeidade emprestada da experiência natural.

Uma ontologia da corporeidade seria pois não somente ilusória, mas também nefasta. Do mesmo modo, os três critérios que distinguem o corpo - a independência em relação ao nosso espírito, a extensão, a função de sujeito dos acidentes - não se unificam num discurso sobre a essência dos conpos ${ }^{(13)}$. Longe de ser um fracasso, esta impossibilidade ao contrário alarga o campo no qual será possível a atualidade verificadora do real, a enunciação motivada do corpo.

É ainda em nome desta ampliação que Hobbes, de maneira definitiva, proclama a impossibilidade de admitir uma Criação ou de uma geração dos conpos. Pois o que é visado aqui é precisamente todo discurso que pretenda falar sobre os corpos, independentemente de seus acidentes. Não somente um tal discurso é injustificado (impossível de ser motivado), como também admitir sua possibilidade seria arruinar qualquer discurso sobre o real, destacando do real nossa experiência dos acidentes dos corpos, que é justamente aquilo do qual se pode falar em geração e conhecimento.

\section{2. o corpo como razão}

A doutrina do corpo em Hobbes é portanto bastante forte para valer como arma ofensiva contra a ordem de razões da metafísica. Com efeito, não somente ela mostra que a ordem das matérias não acede à razão e à verdade, mas ainda levanta a suspeita de que a escolha temerária da metafísica concuza a um embaralhamento das ordens, tomando a razão pelas coisas. E este poder argumentativo que encontramos condensado no De corpore vai de par com uma acepção rigorosa do corpo. Exigência acrescida, por exemplo, no que concerne à identidade e à individuação. Mantido numa contingência e numa singularidade sem remédio, o corpo hobbesiano deve tirar sua identidade própria apenas da relação que mantém com os acidentes. Nenhuma garantia exterior, nenhum olhar que o confirme em sua identidade vem em seu auxílio. Nem Sócrates, nem o barco de Teseu passam vitoriosamente por esta prova, segundo os termos do capítulo XI da segunda parte do De corpore... É que a decomposição de partes que, por sua vez, mudam, longe de contribuir com a identidade por sua solidariedade, antes contribuem para desfazê-la através de suas incessantes mudanças. Um corpo composto, exposto a mutações, não revela em suas mudanças a chave de uma unidade orgânica interna. Bem ao contrário, só se pode ver unidade num corpo que muda se já tivermos postulado esta unidade. Aqui Hobbes é aristotélico: o orgânico não é a virtude da ligação que se pensaria existir na base das partes reunidas; ao contrário, é a unidade orgânica que aceita manifestar-se na pluralidade das partes. A unidade da pluralidade não se constrói pois facilmente: ela não se constrói absolutamente a partir da multiplicidade, mas exige a unidade de um movimento, de uma ação. É por isto que a unidade de um corpo composto, seu verdadeiro princípio de individuação é, definitivamente, o de um "princípio de movimento", como o afirma Hobbes neste mesmo capítulo, evocando a corrente de um rio e a instituição da cidade política, precisamente ${ }^{(14)}$.

Se a insistência sobre as "partes extra partes" constitutivas dos corpos caracteriza o mecanismo, Hobbes participa dele no mais alto grau: ousemos mesmo chamá-lo um mecanista trágico, pois nada salva a unidade da multiplicidade sem um princípio exterior a ela. Doutrina que não é somente política, mas de antemão física.

Contudo, este rigor na exigência da identidade do corpo é também o que the confere o direito de valer como razão das matérias. O corpo não é somente a presa da multiplicidade, externa ou interna. Ele é também o único recurso da unidade e da identidade. Lembremos o exemplo que a continuidade de um fio diretor traça na cadeia todavia sinuosa das obras de Hobbes, desde - Curto Tratado até o De corpore ${ }^{(15)}$ : o monte de areia que se vê de longe não seria um monte sem a ação individual de cada um dos grãos, e que contudo se perde no resultado visível. É insensivelmente que cada corpo 
age. Esta ação individual é racional relativamente à explicação da visão do monte. Não renunciemos pois a encontrar a unidade do princípio do movimento, de acordo com a unidade do corpo: Hobbes havia de início falado de species, que são, diretamente, um corpo. Doravante ele falará de conatus, este ponto de movimento que revela uma unidade corporal, e salva melhor a relação das coisas sem abandonar o horizonte da unidade do corpo: cada grão de areia exerce seu conatus: eis a razão da visão do monte (mas a explicação completa vai requerer contudo um outro conatus, o do sujeito que sente, único detentor da unidade da visão do monte) . Graças ao conatus, o movimento salva a significação racional do corpo; o corpo volta a ser o lugar da determinação do movimento, e fixa assim a sua razão.

Este edifício pode ser mantido em filosofia política, na qual é pouco frequiente a obstinação de seguir a ordem das matérias? Não seria preciso, mais do que em outros domínios, refugiar-se numa ordem de razões para justificar, explicar, reconstruir a ordem invisível da justiça e da autoridade política? Hobbes manifestamente não acredita nisto, pois ele crê poder dar um sentido e uma função de racionalidade ao corpo político, fora de toda metáfora.

Esta estranha aposta de Hobbes tem para nós um sentido político que emerge de sua própria estranheza, uma vez dissipada a tentação dos falsos reconhecimentos. Pois seria necessário reencontrar aqui toda a originalidade e o rigor da análise do corpo, no estado definitivo de sua ciência política: o Leviatã mais particularmente, onde todavia ele não aparece de imediato. É aí que o tema do corpo político surpreende mais: ausente dos capítulos consagrados à geração da Commonwealth e à constituição da unidade da República, ele reaparece em seguida, bastante inoportunamente, parece, sob a estranha forma de corpo orgânico - no qual o artifício parece perdido, e o rigor conceitual parece ter sido trocado por uma metáfora desgastada... . Hobbes insiste: a liberdade dos súditos é o movimento do corpo (cap. XXI) , sua composição em organizações subordinadas são sua organização (cap. XXII) , os ministros públicos as partes orgânicas (cap. XXIII), a vida econômica sua nutrição e sua digestão (cap. XXIV), seus conselheiros sua memória e seu discurso mental (cap. XXV), suas leis civis sua sabedoria (cap. XXVI), em correlação com os crimes e perdões, os castigos e recompensas são seus nervos e os tendões (cap. XXVII e XXVIII), as coisas que enfraquecem a República são suas doenças (cap. XXIX), enfim, a "função do soberano representante é sua alma" (cap. XXX) .

Admitiríamos hoje em dia sem discussão que a convenção política cria um corpo de República imediatamente marcado por propriedades de unidade interna adquiridas unicamente do artifício. Duas razões nos levam a isso: de um lado, admitimos sem dificuldade que a estrutura do Estado seja ela mesma a razão de seus direitos e propriedades. A idéia de uma obrigação política cuja fonte é o Estado não nos choca absolutamente. De outro lado, admitimos facilmente que a associação de partes seja equivalente à unidade de um todo. O ideal democrático erigido em lugar-comum passa por estas duas teses reunidas: admitimos que um direito nasça do Estado, como exigimos que as partes engendrem um todo. Uma exigência leva à outra. Hobbes não partilha de nenhuma destas teses que condicionam fundamentalmente nossa concepção de um corpo político.

De uma parte, não há obrigação política propriamente dita em Hobbes, se entendemos por isto uma obrigação originada com a lei civil. A obrigação de se conformar à lei civil não provém desta, mas da lei natural: "... somos obrigados a uma obediência civil (por meio da qual a lei civil adquire toda sua força) antes que as leis civis sejam estabelecidas..." (De cive, II, cap. XIV, parágrafo 21) . Sob certos aspectos, esta tese é a própria just ificação da convenção política. Quanto à segunda tese, de outro lado, Hobbes, como veremos, não admite que se possa facilmente dispensar a associação ao todo.

Hobbes não é portanto democrata no sentido em que nós entendemos a palavra, porque o próprio quadro deste temo lhe é estranho. Não admitindo que a obrigação surja do próprio Estado, ele não precisa exigir da constituição do corpo político o título de depositário da razão do político. Sua argumentação é muito mais antedemocrática do que antidemocrática: digamos, mais precisamente, que quando argumenta contra a democracia, ele não está falando da nossa democracia.

Notemos que acontece o mesmo com a razão do político; ao atribuir a obrigação civil à lei natural e à convenção, ele justifica em larga medida a 
manutenção de uma ordem de matérias: é somente quando o Estado se apresenta como razão de suas atribuições que sua constituição deve apresentarse como racional. Não tendo se submetido à primeira restrição, Hobbes tem o direito de não se submeter à segunda.

É por esta razão que o abandono, no Leviatã, da tese segundo a qual todo Estado começa pela forma democrática (tese ainda sustentada no De cive) corresponde em Hobbes a uma melhor coerência em sua doutrina. E, numa época (1651) próxima de terminar o De corpore (1655), talvez seja justamente esta doutrina do corpo que o previne contra uma espécie de paralogismo entre o todo e as partes. Do fato de que, como bom nominalista, ele identifique um todo à soma de suas partes, segue-se que a soma dos indivíduos de uma multidão, mesmo que seja por convenções, constitua um todo? A hipótese da etapa democrática supunha isto. Mas trata-se de fato de um paralogismo. Um indivíduo só pode ser parte se já existir o todo que o quantifica como parte. Um grão de areia só é parte de um monte se supusermos o monte: ora, não se passa do grão de areia ao monte sem sujeitar-se à lei da exterioridade entre o sujeito que sente e o objeto sensível... Antes de ser parte do monte, e independentemente desta qualificação a posteriori, o grão de areia exerce seu conatus. Este pode ser estudado a priori... A exigência e o rigor da doutrina do corpo, dos quais o De corpore é testemunha, são talvez, paradoxalmente, o que explica a maior prudência que Hobbes manifesta no manuseio do tema do corpo político no que se refere à geração da República, e sua preferência pela noção de pessoa pública, única noção presente no importante capítulo XVII do Leviatã.

Os comentadores sempre tropeçaram em duas dificuldades de interpretação da convenção exposta nos capítulos XVII e XVIII: de um lado, a posição de Hobbes a respeito da questão da unanimidade e da maioria não é clara. Com efeito, as chas formulações coexistem, a algumas linhas de distância ${ }^{(16)}$ na apresentação que sintetiza o efeito das convenções de cada um com cada um. De outro lado, a exterioridade na qual o soberano é mantido, já que ele não toma parte na convenção, não cessou de suscitar os comentários os mais contraditórios ${ }^{(17)}$. A objeção é conhecida: não é a confissão de que Hobbes deixa o soberano em estado de natureza, fracassando assim lamentavelmente no próprio princípio da instituição do poder civil?
A questão que nos ocupa encerra talvez uma única solução para estes dois problemas. Que a unificação das convenções múltiplas conduza a um "como se" definido pelo abandono declarado de cada um, em favor do soberano, de seu direito de governar, com a condição de que cada outro faça o mesmo, isto equivale bem à unanimidade. E é tanto mais verdade que deste modo cada um autorizou a vontade assim construída, inclusive por uma decisão à qual ele não subscreveria, o que significa que a unidade vale para todos, implicando assim o equivalente de uma cláusula majoritária. Todavia, não haveria flutuação na formulação, a não ser que a associação constituísse por si mesma um conpo. Neste caso, poder-se-ia colocar a questão de sua relação com as partes como devendo ser uma ou outra das respostas. Ora, se Hobbes retirou aqui o termo de corpo, é precisamente porque a unidade assim produzida não é absolutamente a de um todo relativamente às suas partes. Produzir uma pessoa pública, aqui, na pessoa do soberano, é produzir uma unidade precisamente exterior ainda àquilo que ela une. 0 soberano, justamente, é exterior à convenção, e sabe-se que a multidão não se representa nele, como se tratasse de uma relação interna, mas por ele, agindo como agente próprio. Em relação a esta exterioridade, nem a unanimidade nem a maioria constituem um todo. A insistência sobre tais condições corresponderia antes para Hobbes a uma inoportuna investigação dependente de uma ordem de razões ilusória, como se o todo pudesse preceder sua constituição, dando-lhe de imediato a modalidade de sua relação com as partes: isto evidentemente seria pressupor o que só vale como resultado ainda por vir: o todo da República, seu corpo, exige decididamente mais do que a simples associação das convenções individuais. Manter neste caso a ordem das matérias é economizar o desvio de uma condição de universalidade prévia à geração da Commonwealth. Não se poderia exigir uma tal condição sob o pretexto da racionalidade a não ser recaindo na falta de uma verdadeira petição de princípio, introduzindo a unidade do todo como condição de sua constituição.

Se bastasse que os indivíduos se autodeclarassem como partes de um todo para que este todo existisse, as convenções seriam certamente algo mais do que palavras, ou ainda, se se quiser, as palavras conduziriam o mundo. Tal não é, como se sabe, a opinião de Hobbes, o nominalista. É 
preciso algo mais do que convençães, determina o capítulo XVII: um poder comum.

O poder "comum" faz a transição entre a unidade exterior do soberano, que detém a pessoa da multidão como uma coisa diferente dele, e o toob da República, que não deixa de ser o objetivo visado por Hobbes, mas que a convenção não bastou para criar, e que o soberano não está em condiçães de produzir sozinho. É claro que é o poder de todos que se encontra concentrado num só. Neste sentido, o poder dá um passo em direção à reabsorção da exterioridade do soberano. Contudo, ele não poderia ser suficiente para fundar a identidade de um corpo político. Como mostra a equivalência no capítulo XX entre a República de instituição e a República de "aquisição", nascida unicamente do efeito da dominação - equivalência perturbadora para muitos comentadores que vêem aí a ruína de todo um edifício do direito político -, o poder não faz nada mais do que a soma de convenções, se é que não faz menos: a unificação que se pode esperar dele é estritamente paralela à do direito instituído, precisamente: tal é o sentido da equivalência. Pois assim como o direito é uma relação entre vários homens, do mesmo modo o poder é, na mesma medida, da natureza de uma relação entre corpos, mais do que da natureza de uma propriedade individual (como será em Locke) . Lembremos a doutrina do De corpore sobre este ponto: um poder é definido pela presença num agente de todos os requisitos de um efeito futuro (II, cap. X, paragr. 1) : mas Hobbes acrescenta um "detalhe" que tem sua importância: "si modo ad patiens applicatum fuerit". A presença do paciente condiciona a suficiência do poder do agente: o poder se constitui pois com a condição desta dualidade do agente e do paciente. Deve-se pois concluir que o poder não poderia sozinho construir a identidade de um corpo como todo, mas antes necessita ao contrário desta identidade como estabelecida, já que ele se define a partir de uma divisão prévia entre o agente e o paciente.

Portanto, quer se trate de física ou de política, o conpo, para Hobbes. não tem uma simples unidade de composição. Seu modelo não é a agregação externa das partes, mas a unidade orgânica que as regula. Nem a relação de direito, nem a relação de poder chegam assim a fazer um verdadeiro toodo, pois elas só são definidas a partir das multiplicidades. Quanto ao privilégio aparente da forma mais abstrata de unidade - a pertinência - com a qual alguns poderiam contentar-se, ele provém somente do fato da realidade da união ser pensada como a realização de uma essência, de uma propriedade. A ligação duvidosa entre a parte e o todo, ao mesmo tempo muito frouxa (a oposição entre o de dentro e o de fora basta neste caso) e por demais rigorosa (é ao mesmo tempo, de fato, o segredo totalitário: o todo como tendo o monopólio da ligação) cai neste erro: a essência do elo só é aceita como equivalendo ao ser do todo...

O modelo orgânico se justifica em Hobbes por uma crítica desta concepção que confunde a ordem das razões e a ordem das coisas. Longe pois de sancionar o fracasso de um modelo de geração artificial do corpo políti$\mathrm{co}$, ele exprime ao contrário a exigência suplementar a respeito das condições de existência de um corpo político. Uma unidade de composição não seria senão ilusoriamente uma unidade política real. Seria um agregado de corpos, como ela o é também, a título subsidiário, como formada destas partes "homeômeras" (corpos menores) . O verdadeiro, contudo, não está aí, mas na ligação orgânica que autoriza a falar de suas partes "nãohomeômeras", ou seja, diferenciadas na natureza e nas funções. Aristóteles já proclamava isto contra Platão: vendo na cidade apenas a condição de unidade, perdemos a realidade da unidade política ${ }^{(18)}$.

Pode-se assim, paradoxalmente, responder às numerosas objeções nascidas das aparentes negligências de Hobbes no que concerne às formas de exterioridade "residual" que ele mantém, de maneira pouco compreensível, na sua Commonwealth: não somente são deixadas livres as mãos do soberano, ao abrigo de qualquer controle interno ao Estado, mas ainda, em sentido inverso, a manutenção do direito natural de cada um de resistir à condenação à morte, mesmo decretada legalmente, ou ainda a filiação aceita por Hobbes do direito de punir, associando este direito não ao poder civil, mas ao contrário, a um direito herdado do estado de natureza. Seu verdadeiro laxismo em matéria de obrigações militares também não deixa de surpreender: com efeito, cada cidadão não pode se fazer substituir por outro que o queira no exercício desta obrigação. . . ? É precisamente uma unidade de simples composição, que construiria a unidade do corpo político de imediato como unidade de um todo, que tornaria possível a manutenção destes elementos não integrados. A partir do momento em que a unidade do corpo 
político é uma unidade de ação, estes elementos não devem ser pensados como se fossem incompatíveis com a identidade do corpo. Não é da unidade das partes que provém a unidade do corpo. o corpo recebe sua unidade do fato de sua ação ser a ação de todas as suas partes.

Será mesmo realmente necessário desculpar Hobbes por ele ter assinalado a existência de relações externas no seio do Estado? Um tal procedimento seria mesmo altamente paradoxal, já que procuraria querer salvar a doutrina de Hobbes malgrado ela mesma, malgrado estes "resíduos" chocantes que alterariam a racionalidade que se considera que ele visa: de fato, a nossa racionalidade. Ora, é claro que não é "a despeito" destas marcas de exterioridade das partes do Estado umas em relação às outras, mas "por causa" delas que é preciso fazer justiça à razão política em sua versão hobbesiana. O fato de a unidade política por ele descrita não passar pela redução destas fontes de exterioridade é a prova não de sua fraqueza, mas, ao contrário, de sua força. E estaria mesmo tão enganado ao assinalar o caráter inevitável da exterioridade do soberano?

Aceitemos assim mudar nossa leitura de Hobbes. Poderemos então ver que a ordem das matérias, da qual o tema do corpo é o termo privilegiado, está longe de trair a vocação que Hobbes the atribui, a de fornecer uma melhor razão. Para compreender isto, é preciso somente dar as costas à metáfora do corpo como tal: pois é verdade que o uso desta metáfora opera de modo inverso, dando uma figuração, uma aparência de matéria a uma ordem de razões que por isto mesmo tornou-se autônoma. o corpo como metáfora política serve então de simples etapa para uma razão por demais abstrata. A razão de Estado, o espírito de corpo, e todos os temas de uma subjetividade requal ificada graças à simples inserção no imaginário do corpo são assim os frutos desta ilusão. O procedimento de Hobbes, como se vê, é exatamente oposto ao outro: não dar um corpo ao Estado para construir para ele, a um custo menor, uma alma. Bem ao contrário, segundo ele, o corpo se esboça uma vez que a alma - o soberano - tenha emergido completamente. 0 corpo político é o mais difícil resultado, e não o expediente da razão política.

O fato de o corpo político ser assim um instrumento da razão na ciência política de Hobbes tem importantes consequiências em toda a sua doutri- na. Considerando isso mais atentamente, ele abre assim um novo espaço para as relações jurídicas, a respeito das quais seria inútil acreditar que sejam compatíveis com a visão simplista de uma unidade de pertinência fechada sobre si mesma. O direito é relação entre vários. Hobbes, longe de negá-lo, chega até a aceitar, por exemplo, que o próprio Estado seja julgado. Segundo ele, isto é possível sem atentar contra a unidade do soberano e contra seu estatuto de legislador exclusivo. Basta não acreditar que, num tal procedimento, seja constituída uma instância supra-estatal. Mas ainda aqui, uma tal ilusão de jurista se dissipa diante da existência de um corpo políti$\mathrm{co}$ : um direito imaginado por juristas, como aqueles que eles reivindicam sobre a base de sua prudência, não poderia vencer a prova de verificação que constitui a relação com o corpo político, e que nos reconduz à sua condição primeira, a unicidade do soberano, detentor do poder comm.

Esta unicidade, todavia, não nos encerra de novo num imaginário simplista da unidade figurada. A unicidade pensada e não figurada da soberania passa, curiosamente, ela também, por relações mais complexas do que a posição do monopólio. Autorização, personificação e representação, todas as três implicadas pela soberania, não são relações que se fecham numa autosuficiência. A autorização em Hobbes não perde seu sentido transitivo, de sorte que ela não se fecha nunca sobre uma autoridade em si. A representação, como se sabe, também não se fecha independentemente de uma relação multilateral entre vários súditos. Quanto à noção de pessoa, entendida no sentido jurídico, ela é por natureza um papel que se distribui entre os súditos. A unicidade de um termo (o soberano, ou ainda, o povo) portanto não tem nada a ver com a definição da unidade de um todo, que supõe sempre uma relação única (a pertinência) e uma saturação trivial de seu domínio de exercício (todas as partes estão nela, sempre e simultaneamente em jogo) .

Estas formas - que podemos qualificar de jurídicas ou de quase jurídicas - não são as únicas a manter uma multiplicidade interna da República. Grupos e indivíduos subsistem como tais do estado de natureza. Em termos de corpo, eles são agentes bem antes de ser partes da República. Corporações, monopólios, privilégios, desigualdades, tendem a aumentar as ocasiões de multiplicidade. É por isto que sua qualificação como partes orgâ- 
nicas possui um lugar teórico decisivo. Não é preciso menos do que o equivalente da vida para que elas possam ser contadas como partes, e não como corpos estranhos. A vida do grande Leviatã - sua ação centrada sobre si mesmo, a vida do estado mercantilista - é necessária para que se possa simplesmente falar de um todo, para o que uma associação está longe de ser suficiente. A vida orgânica é a condição mínima para que a unidade da República tome a forma de um todo, de um corpo composto verdadeiro. Daí o célebre frontispício do Leviatã: a forma de um homem vivo é necessária para fazer de uma multiplicidade um todo simples. Nem é mesmo necessário concluir aqui por um abandono do mecanicismo: ao contrário, a exigência da vida do corpo político é testemunha da vocação que os conpos têm de permanecer como "corpora extra corpora..." e da dificuldade a ser vencida por isso mesmo...

Assim, contra as interpretações "construtivistas" do artifício hobbesiano, é preciso ver nele menos uma geração definida por uma composição do que, ao contrário, a geração no sentido de uma unidade do corpo político enfim trazido à plena luz, para além da simples relação de composição, que, precisamente, não é suficiente. A unidade orgânica significa então que esta unidade é compreendida, conduzida à racionalidade porque é artificial. A Cormonwealth é um homem cuja opacidade das ligações vitais é vencida graças ao artifício. No homem natural, sabe-se que estas ligações permanecem para sempre como um segredo da Criação. Orgãos, funções, tomam-se ao contrário, no caso político, objetos de um saber a priori.

Se se pode assim admitir que Hobbes faz de sua noção de corpo um instrumento da razão para sua ciência política, a verdadeira questão que resta é a de saber por que neste ponto nos repugna admitir que uma ordem das matérias possa dar lugar a outra coisa que não sejam metáforas em filosofia política. A resposta talvez esteja em nossa mais duvidosa aquisição neste domínio, a História. De fato, para nós, o Estado é um conpo no senti- do metafórico: pois para nós ele é imerso na História, que é a única que tem condições para engendrar sua identidade. O corpo do Estado não é então senão uma unidade delegada, imagem que a História quer dar a si mesma. Hobbes, por sua vez, não afrontava menos a contingência e as multiplicidades dos acidentes históricos, com seu estado de natureza. Mas, longe de fazer deles uma circunvizinhança do Estado, ele os pensava no interior do Estado. É o Estado que é a verdadeira unidade - um corpo não metafórico e não a História. A uma história que acaba mal, ele denomina uma doença da República; pois cabe ao político normalizar a contingência histórica, que está nele.

Para nós, esta contingência vem de outro lugar, e se crê, correlativamente, que o político só concerne à sua própria racionalidade. Entre os dois pontos de vista, qual é o mais fecundo? Poderia bem acontecer que a mais pobre das duas razões políticas não seja, em definitivo, aquela que Hobbes apóia com a evocação do Leviatã, este grande animal um pouco monstruoso, e sobretudb, tão vulnerável...

Abstract: The purpose of this article is to discuss Hobbe's notion of "book" and to show that it is not a mere organic metaphor or a effect of an physical reduction, but a first possibility of sense for all sciences. In this way, Hobbes can understand the political booky without the illusions conceming the establishment and the unity of Commonwealth.

Key-words: Hobbes - political body - organism 


\section{Notas}

(1) Esta é a opinião de D. G. Hale (Hale 2, p. 108). E. Kantorowicz, que na verdade se coloca a partir de um ponto de vista diferente em Les deux corps du roi (Kantorowicz 4) assinala (por exemolo, na página 323) sobretudo a longevidade da metáfora orgânica, que, na Inglaterra, obteve sua carta de nobreza na obra de Fortescue (1385-1479) intitulada De Laudibus Legum Angliae. J. Schlanger, em Les métaphores de l'organisme, exprime o essencial daquilo que o jurista Jellinek denunciava, por sua vez, como o emoirismo subjetivo da metáfora: "a vida do todo orgânico é deste modo encerrada na intuição que nô-la entrega" (Schlanger 8, p. 219).

(2) Evoquemos por exemplo somente Metafísica $M$, capítulo 2, 1077a31, a propósito da perfeição dos corpos matemáticos, e sobretudo o De coelo (I, capítulo 1, 268 b), onde Aristóteles assimila o corpo a um gênero.

(3) Cf. De corpore, I, cap. VIII, parágrafo 20 (0. L., tomo 1, p. 103). Mas este texto assinala também o aspecto estritamente lógico desta impossibilidade da geração dos corpos: pode acontecer que aquilo a que chamamos corpo num momento seja chamado de não-corpo noutro momento. Aqui estamos próximos do argumento kantiano que diz respeito à fórmula que engana, segundo ele, o metafísico: "as essências das coisas são imutáveis" (Cf. Réponse à Eberhard, Vrin, p. 91) . Quanto à criação ou à destruição dos corpos, elas seriam ininteligíveis na medida em que se refeririam aos corpos independentemente de seus acidentes (Cf. De conpore, I, capítulo I, parágrafo 8. In: O. L., tomo I, p. 9) . É claro que, mesmo aqui, isto não significa negar a dependência dos corpos em relação ao Criador, que Hobbes afirma, tanto mais porque nenhum corpo tem em si mesmo o seu princípio de movimento (Cf. De corpore, IV, capítulo XXX. O. L., tomo I. p. 415).

(4) De corpore, I, capítulo I, parágrafos 8 e 9, onde se diz que o objeto geral da Filosofia (e, portanto, da ciência) é "todo corpo cuja geração pode ser concebida".

(5) Sobre a divisão do domínio do saber em dois ramos, o parágrafo 9 do capítulo I do De corpore concorda em todos os pontos com o capítulo IX do Leviatã, pelo menos em sua versão inglesa de 1651 .
(6) Cf. De corpore, capítulo XXV, parágrafo 5 (O. L., I, p. 320) : toda sensação é reação, mas nem toda reação é sensação.

(7) De conpore, I, cap. 2, parágr. 6 (O. L., I, p. 16) .

(8) De conpore, I. cap. III, parágr. 3 (O. L., I, p. 28) . Esta assimi lação se deve ao contexto da proposição, no qual o nome de corpo toma sua significação de predicado.

(9) De corpore, I, cap. III, parágr. 3 (O. L., I, p. 29) : "homina autem abstracta causam nominis concreti denotant, non ipsam rem".

(10) Cf. G. Ockham, Summa Logicae, I, 10, 34, sobre a definição dos termos conotativos, como significando primordialmente uma coisa e secundariamente uma outra. "Branco" assim significa secundariamente brancura, o que Hobbes denominará o nome abstrato motivando o nome concreto. Já em Ockham, o termo conotativo "corpo", do mesmo modo que "figura", "altura, "largura" e todos os termos quantitativos em geral, tinha o privilégio, sobre o termo "branco", de não conotar uma coisa deteminada que era preciso estabelecer de modo independente. Neste sentido, esta categoria de termos conotativos tinha um sentido "absoluto" (Cf. R. Ieff 5, pp. 142 e segs.). Hobbes na realidade se apropria deste caso para que ele exerça o papel que em Ockham era exercido pelos temos "absolutos, livres de conotação" (substância e qualidade). Para Hobbes, portanto, não há termos livres de conotação. Esta é a regra do discurso humano.

(11) Cf. Décima quinta objeção sobre a Sexta Meditação, O. L., V, p. 273. Evidentemente é a garantia divina que está em questão.

(12) De corpore, I, II, parágr. 14 (O. L., tomo I, p. 22) : "... atque sic videmus compositionem conceptum in animo respondere compositione nominum... Cavendum tamen est ne putemus eodem modo componi ipsa corpora extra animum". "A ordem dos nomes segue a ordem de nossas concepções, mas esta não corresponde à ordem dos corpos fora de nós". Evidentemente, esta distorsão se resolve para Hobbes através das condições colocadas para a imposição de nomes.

(13) O texto do De corpore, I, cap. VIII, parágrafo 1 (O.L., I, pp. 90-91) que define o corpo enuncia muito claramente estes três critérios sem tentar unificá-los. 
(14) De corpore, II, cap. XI, De eodem et diverso, parágrafo 7 (O. L., I, p. 122 ). O critério do "principium motus" vem mais claramente em auxílio da identidade nominal no caso do rio e da cidade do que no caso de Sócrates (já que seu princípio vital, derivado da criação, permanece escondido para nós) ou do barco de Teseu (do qual se poderia dizer que tem vários princípios de movimento...). .

(15) A continuidade das obras da maturidade com o Short tract on first principles, de 1630 aproximadamente, não é sempre tão manifesta quanto neste exemplo da visão do monte de areia, que se encontra mais ou menos idêntico, com a diferença de que as "species" da primeira doutrina da visão são substituídas pelos "conatus", ampliando assim a problemática do corpo... e da racionalidade. O problema colocado por este exemplo é emblemático de toda a questão da recução da multiplicidade à unidade em Hobbes, e por isto mesmo é revestido de uma grande significação. Cf. Short Tract, seção 2, parágrafo 6, ed. Tonnies, p. 199200. De corpore, III, cap. XXII, parágrafo 9 (O. L., I, p. 279) .

(16) É o que observa de modo pertinente, por exemplo, Mac Neilly (6, p. 219). M. Goldsmith (1, pp. 155-161) atribui por sua vez ao Leviatã a fómmula da unanimidade. Lucien Jaume é certamente melhor inspirado ao acentuar que o Leviatã põe fim à transição através da soberania popular que era admitida nos dois tratados políticos precedentes, e que há nele uma verdadeira "ruptura epistemológica" (Jaume 3, sobretudo pp. 71 e 120-124).

(17) H. Warrender (citado aqui na edição de 1966) confessa o que muitos outros comentadores pensam sem dizer: a insistência de Hobbes em manter o soberano fora da convenção cria problemas para sua doutrina (Warrender 9, p. 134). Por isso ele tenta minimizar esta "exterioridade". Outras estratégias de comentários são possíveis: P. Manent, como R. Polin, prefere levar a tese ao extremo para salvá-la: ".. .mas porque ele é o único em estado de natureza, o estado de natureza fica abolido" (Manent 7, p. 65). Solução que L. Jaume (3, p. 80) julga insatisfatória...

(18) Cf. Aristóteles, Política, II, capítulo 2, 1261b 7. Ed. Tricot, Vrin, t. 1, p. 87): "a cidade não possui por natureza esta unidade absoluta que alguns Ihe atribuem, e aquilo que se indicou como sendo o maior dos bens para as cidades é na realidade aquilo que as conduz à ruína". De uma certa maneira o artifício hobbesiano confima a tese aristotélica.

\section{Bibliografia}

1. Goldsmith, M. Hobbes's Sience of politics. 1966.

2. Hale, D. G. The booky politic, a political metaphor in Renaissance English literature. Mouton, 1971.

3. Jaume, L. Hobbes et l'État représentat if moderne. Paris, PUF, 1986.

4. Kantorowicz, E. Les deux corps du roi. Paris, Gallimard, 1957 e 1989.

5. Leff, R. William of Ockham. The metamorphosis of scholastic discourse. Manchester University Press, 1975.

6. Mac Neilly. The anatomy of Leviathan. Mac Millan 1968.

7. Manent, P. Naissances de la politique modeme. Paris, Payot, 1977.

8. Schlanger, J. Les métaphores de l'organisme. Paris, Vrin, 1971.

9. Warrender, H. The political philosophy of Hobbes. Oxford, Clarendon Press, 1957 (1966) . 